О. О. Аемішко,

к. е.н., дочент, дочент кафедри фінансів Начіонального

університету біоресурсів і природокористування України, м. Київ

ORCID ID: 0000-0002-6216-652X

DOI: 10.32702/2306-6814.2019.8.45

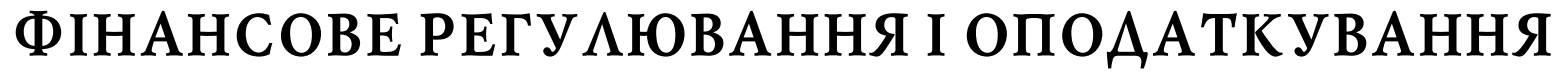

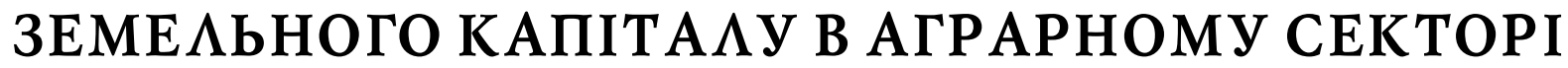 ЕКОНОМІКИ УКРАЇНИ
}

\author{
O. Lemishko, \\ $\mathrm{PhD}$ (Economics), Associate Professor of the Department of Finance, \\ National University of Life and Environmental Sciences of Ukraine, Kyiv
}

\section{FINANCIAL REGULATION AND TAXATION OF LAND CAPITAL IN THE AGRARIAN} SECTOR OF THE UKRAINIAN ECONOMY

Предметом дослідження є теоретичні засади, методичні основи і практичні аспекти фінансового регулювання і оподаткування земельного капіталу в аграрному секторі економіки України. Методологічною та інформаційною основою роботи є наукові праці, матеріали періодичних видань, ресурси Internet, нормативно-правові акти з питань оподаткування земельного капіталу, офіційна звітність Державної служби України з питань геодезії, картографії та кадастру. При проведенні дослідження використано методи суб'єктно-об'єктного і структурного аналізу грошової оцінки земель сільськогосподарського призначення та їх оподаткування. Обгрунтовано комплекс заходів, орієнтованих на зростання ролі оподаткування земельної власності у розвиткуаграрного сектора економіки: реформування підходів до надання пільг - встановлення їх відповідно до об'єкта, а не платника податку, а також ув 'язка з реалізацією загальнодержавних і регіональних програм розвитку земельного ринку і охорони земель; проведення екологоагрохімічної паспортизації та інвентаризації земель на предмет відповідності об'єкту оподаткування; поступовий перехід до використання ринкової вартості землі як бази оподаткування; диференціація земельної нерухомості за рівнями якості сільськогосподарських угідь; введення фінансових і адміністративних санкцій за неналежне використання сільськогосподарських земель і недотримання екологічних норм; стимулювання засобами податкової політики збільшення терміну оренди рілля і багаторічних насаджень для забезпечення відповідального ставлення орендарів; унеможливлення оподаткування земельного капіталу великих сільськогосподарських суб'єктів оподаткування за спеціальними режимами, призначеними для малих організаційних форм агробізнесу. Доведено, що обов'язковою умовою відміни мораторію на здійснення операцій відчуження сільськогосподарської землі є створення автоматизованої системи ведення державного земельного кадастру, обліку надходжень від плати за землю, контролю їх повноти і своєчасності.

The subject of the study is theoretical principles, methodological bases and practical aspects of financial regulation and taxation of land capital in the agrarian sector of the Ukrainian economy. Methodological and informational basis of work are scientific works, materials of periodicals, Internet resources, normative legal acts on questions of taxation of land capital, official reports of the State Service of Ukraine on issues of geodesy, cartography and cadastre. In the course of the research, methods of subjective and objective and structural analysis of the monetary valuation of agricultural land and their taxation were used. The complex of measures focused on the growth of the role of taxation of land ownership in the development of the agrarian sector of the economy is substantiated: the reform of approaches to the granting of privileges - their establishment according to the object, and not the taxpayer, as well as the linkage with the implementation of national and regional land 
market development programs and the protection of land; conducting ecological - agrochemical certification and inventory of land for the subject of compliance of the object of taxation; gradual transition to the use of market value of land as a tax base; differentiation of land properties by quality levels of agricultural lands; introduction of financial and administrative sanctions for improper use of agricultural land and non-compliance with environmental norms; stimulating by means of the tax policy the increase of the term of lease of arable land and perennial plantings to ensure a responsible attitude of tenants; impossibility of taxation of land capital of large agricultural subjects of taxation under special regimes intended for small organizational forms of agribusiness. It is proved that the mandatory condition for the abolition of the moratorium on the implementation of operations of alienation of agricultural land is the creation of an automated system for conducting the state land cadastre, accounting for revenues from land payments, monitoring their completeness and timeliness.

Ключові слоВа: фрінансове регулюВання, оподаткуВання, земельний капітал, аграрний сектор економіки, оренда, пільги, оцінка, кадастр.

Key words: financial regulation, taxation, land capital, agrarian sector of the economy, lease, privileges, valuation, cadastre.

ПОСТАНОВКА ПРОБАЕМИ У ЗАГА АЬНОМУ ВИГ АЯАІ ТА ЇÏ ЗВ'ЯЗОК I3 ВАЖАИВИМИ НАУКОВИМИ ЧИ ПРАКТИЧНИМИ ЗАВААННЯМИ

Земля є основою буття, об'єктом соціально-економічних зв'язків та виконує багато важливих функцій у виробничій, соціально-екологічній та економіко-правовій площині. 3 початку 90 -их років минулого століття Україна використовує оподаткування землі як джерело наповнення бюджету і регулювання діяльності землевласників та землекористувачів. Незважаючи на те, що з 1996 року в основу оподаткування землі покладена грошова нормативна оцінка, єдиного державного земельного кадастру в нашій країні так і не створено [1, с. 86]. Це ускладнює оподаткування земельного капіталу, негативно позначається на його фріскальному і стимулюючому потенціалі.

\section{АНА $\Lambda$ IЗ ОСТ АНHIX АОС $\Lambda$ IАЖЕНЬ I} ПУБАІКАЦІЙ, В ЯКИХ ЗАПОЧАТКОВАНО

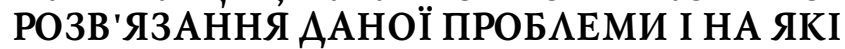
СПИРАЕТЬСЯ АВТОР, ВИАІАЕННЯ НЕ ВИРІШЕНИХ РАНІШЕ ЧАСТИН

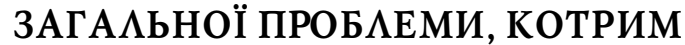
ПРИСВЯЧУЕТЬСЯ ОЗНАЧЕНА СТАТТЯ

Проблеми фрінансового регулювання розвитку аграрного сектора економіки України знаходяться у центрі уваги багатьох учених. Нудьга М.В. відзначає важливу роль земельного капіталу як джерела фрормування доходів місцевих бюджетів [2, с. 100]. Актуальним проблемним аспектом з питань оренди комунального майна, на думку Легенченко М.О. [3, с. 122], є питання визначення платника земельного податку за земельні ділянки під об'єктами нерухомості, що належать територіальним громадам та передаються в оренду. Тесля Л.В. найбільшою вадою адміністрування земельного податку в Україні називає відсутність стимулювання поліпшення якості земельних угідь та грунтів у цілому [4, с. 143]. Іншими недоліками є: велика кількість податкових пільг; занижені ставки плати за землю для певних категорій платників; повільний процес інвентаризації земель, їх недостовірна грошова оцінка; відсутність дієвого покарання за користування земельними ділянками з порушенням земельного законодавства, без сплати податку та орендної плати; не чітка регламентація виникнення податкового зобов'язання зі сплати плати за землю. Левицька С.О., Стець Н.В. акцентують увагу на критичності використання земель в Україні, оскільки подальша деградація потенціалу земельних ресурсів у сільському господарстві матиме катастрофрічні наслідки, які негативно вплинуть на загальний рівень продовольчої безпеки країни, здоров'ї нації тощо [5, с. 108]. Окрім активізації використання традиційних фракторів сільськогосподарського виробництва, удосконалення потребують механізми інституційного характеру, зокрема система оподаткування земельного капіталу.

\section{META CTATTI}

Метою статті $€$ обгрунтування науково-практичних рекомендацій із підвищення ефективності фрінансового регулювання і оподаткування земельного капіталу в аграрному секторі економіки України, орієнтованих на стимулювання розвитку земельного ринку, зміцнення інституту власності на землі сільськогосподарського призначення, їх охорону, раціональне використання бюджетних коштів.

\section{ВИК ААА ОСНОВНОГО МАТЕРІААУ АОС АІАЖЕННЯ 3 ПОВНИМ ОБГРУНТУВАННЯМ ОТРИМАНИХ НАУКОВИХ РЕЗУ $А$ ТАТІВ}

Фінансове регулювання земельного капіталу представлено визначенням правил і умов обігу його титулів на товарному і фінансовому ринках, вартісною оцінкою, обкладанням податками і зборами тощо. Плата за використання земель сільськогосподарського призначення на користь держави у формі земельного податку та орендної плати має фріскальні і регулюючі переваги порівняно з оподаткуванням інших факторів виробництва, серед них: об'єктивне стягування абсолютної і час- 


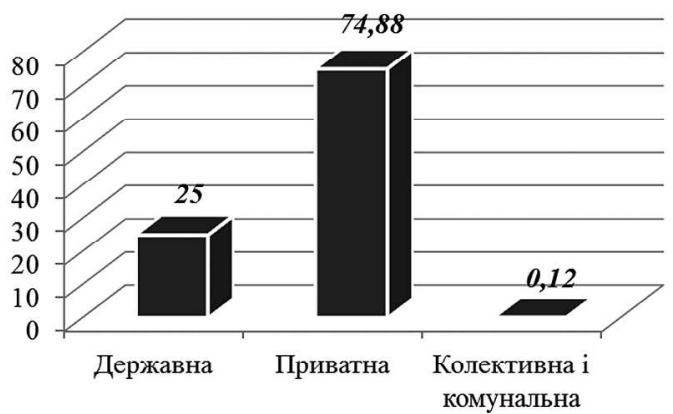

Рис. 1. Структура земельного фонду України станом на 01.01.2018 р., \%

Джерело: побудовано за даними [7].

тини диференціальної земельної ренти; менші можливості ухилення від сплати податку на прибуток через прозорість об'єкта оподаткування; справедливий та рівномірний механізм адміністрування земельного податку; вирівнювання умов господарювання для сільськогосподарських виробників [6, с. 45].

Сільськогосподарські землі $є$ найбільшою категорією земель у структурі земельного фонду України. Його основу (станом на 01.01.2018р.) становить приватна власність (31,09 млн га, або 74,88\%), частка держави (10,38 млн га) дорівнює четвертій частині. Обсяг земель колективної і комунальної власності становить відповідно 0,02 млн га (0,05\%) і 0,03 млн га (0,07\%) та $\epsilon$ мізерною - всього 0,12 \% у загальній структурі земельного фонду України (рис. 1).

Оподаткування земельного капіталу в українських умовах пройшло певний шлях еволюції. У 1998 році було прийнято Закон України "Про фріксований сільськогосподарський податок", який поглинув земельний податок [8]. 3 цього періоду розпочалося роздвоєння оподаткування землі: більша частина сільськогосподарських товаровиробників сплачувала земельний податок у складі фріксованого сільськогосподарського податку, а незначна - земельний податок як самостійний [9, c. 372]. Зазначений Закон України втратив силу у зв'язку з прийняттям Податкового Кодексу України (ПКУ). Главу 2 "Фіксований сільськогосподарський податок" розділу XIV "Спеціальні податкові режими" ПКУ було виключено у 2014 році на підставі Закону України "Про внесення змін до Податкового кодексу України та деяких законодавчих актів України щодо податкової реформи" [10]. Починаючи з 2015 року, 4 група єдиного податку сформована з колишніх платників фріксованого сільськогосподарського податку. Відповідно до статті 292-1 ПКУ "об'єктом оподаткування для платників єдиного податку четвертої групи є площа сільськогосподарських угідь (ріллі, сіножатей, пасовищ і багаторічних насаджень) та/або земель водного фонду (внутрішніх водойм, озер, ставків, водосховищ), що перебуває у власності сільськогосподарського товаровиробника або надана йому у користування, у тому числі на умовах оренди" [11]. Відповідно до п.п. 4 п. 291.4 ст. 291 ПКУ до четвертої групи платників єдиного податку віднесені сільськогосподарські товаровиробники, у яких частка сільськогосподарського товаровиробництва за попередній податковий (звітний) рік дорівнює або перевищує 75 відсотків. Згідно з п.п. 297.1 ст. 297 ПКУ вони звільняються від обов'язку нарахування, сплати та подання податкової звітності із земельного податку, крім земельного податку за земельні ділянки, що не використовуються ними для ведення сільськогосподарського товаровиробництва. Таким чином, для платників єдиного податку IV групи спеціальний режим оподаткування $є$ замінником податку на прибуток, земельного податку та рентної плати за спеціальне використання води у цих суб'єктів [12, с. 51].

Земельний податок - обов'язковий платіж, що справляється з власників земельних ділянок та земельних часток (паїв), а також постійних землекористувачів, під якими розуміють юридичних та фрізичних осіб (резидентів і нерезидентів), яким відповідно до закону надані у користування земельні ділянки державної та комунальної власності, у тому числі на умовах оренди (підпункти 14.1.72-14.1.73 статті 14 Податкового кодексу України [11]). За правовою сутністю земельний податок, $є$ обов' язковим, безеквівалентним, нецільовим платежем у бюджет держави або у бюджети органів місцевого самоврядування, який сплачується платниками (юридичними або фрізичними особами, консолідованим платником) на підставі норм податкового закону.

Результати аналізу динаміки і структури платників податку на землю, нарахованих і сплачених сум земельного податку і орендної плати представлено в таблиці 1. Протягом 2016-2017 років чисельність платників земельного податку і орендної плати зросла з 7380 тис. осіб до 7761,3 тис. осіб. Основна їх частина (близько 98\%) приходиться на фрізичних осіб. За підсумками 2016 року загальна сума нарахувань склала 24142,0 млн грн, ут. ч. за юридичними особами - 88,14\%. У 2017 році відбулося зростання аналізованого показника на 2105,3 млн грн. У структурі загальних платежів (рівно як і фрізичних, і юридичних осіб) за землю переважає орендна плата, у 2016 році вона становила $64,53 \%$, у 2017 році - 62,69\%.

Податкова дисципліна фрізичних осіб є кращою порівняно з юридичними. Рівень перерахування платежів за землю ними складає у 2016 році 101,72\%, у 2017 році - 103,16\%. Тоді як для юридичних осіб зазначені показники складають відповідно 96,61\% і 98,20\%. Це можна пояснити істотною відмінністю у розмірах платежів юридичних і фрізичних осіб, оскільки перші за результатами 2016-2017 років у середньому вищі у 350 разів. За аналізований період середній річний розмір плати за землю фрізичної особи збільшився із 402, 4 грн до 447,86 грн, а юридичної - із 140271,2 грн до 161523,4 грн.

Відповідно до статті 64 Бюджетного кодексу України [13] земельний податок та орендна плата у повному обсязі відноситься до доходів бюджетів місцевого самоврядування. Таким чином, у структурі платників земельного податку та орендної плати до місцевих бюджетів переважну частину складають фрізичні особи, але основну суму надходжень забезпечують юридичні особи. У складі плати за землю основна питома вага приходиться на оренду плату в частині двох груп платників податків.

У таблиці 2 представлено результати аналізу кількості платників єдиного податку четвертої групи юридичних осіб, а також обсягу їх нарахувань. 
Таблиця 1. Аналіз динаміки і структури платників податку на землю, нарахованих і сплачених сум земельного порядку і орендної плати

\begin{tabular}{|l|l|l|l|l|l|l|l|l|l|}
\hline \multirow{2}{*}{ Показник } & \multicolumn{3}{|c|}{2016 рік } & \multicolumn{3}{c|}{2017 рік } & \multicolumn{3}{c|}{ Абсолютний приріст } \\
\cline { 2 - 10 } & $\begin{array}{c}\text { фізичні } \\
\text { особи }\end{array}$ & $\begin{array}{c}\text { юридичн } \\
\text { і особи }\end{array}$ & \multicolumn{1}{|c|}{ разом } & $\begin{array}{c}\text { фізичні } \\
\text { особи }\end{array}$ & $\begin{array}{c}\text { оридичн } \\
\text { і особи }\end{array}$ & разом & $\begin{array}{c}\text { фізичн } \\
\text { і особи }\end{array}$ & $\begin{array}{c}\text { оридин } \\
\text { і особи }\end{array}$ & \multicolumn{1}{c|}{ разом } \\
\hline Кількість платників & 7234500 & 145521 & 7380021 & 7619100 & 142171 & 7761271 & 384600 & -3350 & 381250 \\
\hline Нараховано, тис. грн & 2861881 & 21280128 & 24142009 & 3307795 & 23385418 & 26693213 & 445914 & 2105290 & 2551204 \\
\hline - земельного податку & 1062784 & 7501360 & 8564144 & 1369265 & 8589754 & 9959019 & 306481 & 1088394 & 1394875 \\
\hline - орендної плати & 1799097 & 13778768 & 15577865 & 1938530 & 14795664 & 16734194 & 139433 & 1016896 & 1156329 \\
\hline Структура нарахувань, \% & 100 & 100 & 100 & 100 & 100 & 100 & 0 & 0 & 0 \\
\hline - земельного податку & 37,14 & 35,25 & 35,47 & 41,40 & 36,73 & 37,31 & 4,26 & 1,48 & 1,84 \\
\hline - орендної плати & 62,86 & 64,75 & 64,53 & 58,60 & 63,27 & 62,69 & $-4,26$ & $-1,48$ & $-1,84$ \\
\hline Оплачено, тис. грн & 2911182 & 20412408 & 23323590 & 3412306 & 22963942 & 26376248 & 501124 & 2551534 & 3052658 \\
\hline - земельного податку & 1032274 & 7060957 & 8093231 & 1383737 & 8262337 & 9646074 & 351463 & 1201380 & 1552843 \\
\hline - орендної плати & 1878908 & 13351451 & 15230359 & 2028569 & 14701605 & 16730174 & 149661 & 1350154 & 1499815 \\
\hline Структура оплати, \% & 100 & 100 & 100 & 100 & 100 & 100 & 0 & 0 & 0 \\
\hline - земельного податку & 35,46 & 34,59 & 34,70 & 40,55 & 35,98 & 36,57 & 5,09 & 1,39 & 1,87 \\
\hline - орендної плати & 64,54 & 65,41 & 65,30 & 59,45 & 64,02 & 63,43 & $-5,09$ & $-1,39$ & $-1,87$ \\
\hline $\begin{array}{l}\text { Середній розмір оплати, } \\
\text { грн/особа }\end{array}$ & 402,40 & 140271,2 & 3160,4 & 447,86 & 161523,4 & 3398,4 & 45,46 & 21252,2 & 238,08 \\
\hline - земельного податку & 142,69 & 48521,9 & 1096,6 & 181,61 & 58115,5 & 1242,8 & 38,93 & 9593,6 & 146,21 \\
\hline - орендної плати & 259,71 & 91749,3 & 2063,7 & 266,25 & 103407,9 & 2155,6 & 6,53 & 11658,6 & 91,87 \\
\hline Рівень перерахування, \% & 101,72 & 95,92 & 96,61 & 103,16 & 98,20 & 98,81 & 1,44 & 2,28 & 2,20 \\
\hline - земельного податку & 97,13 & 94,13 & 94,50 & 101,06 & 96,19 & 96,86 & 3,93 & 2,06 & 2,36 \\
\hline - орендної плати & 104,44 & 96,90 & 97,77 & 104,64 & 99,36 & 99,98 & 0,21 & 2,47 & 2,21 \\
\hline
\end{tabular}

Джерело: побудовано за даними [7].

Протягом 2016-2017 років кількість платників єдиного податку четвертої групи - юридичних осіб скоротилася із 34184 осіб до 32627 осіб, або на $4,55 \%$. Ïx питома вага у загальній кількості юридичних осіб платників земельного податку і орендної плати складає близько $23 \%$. Сума нарахованого єдиного податку у 2016 році склала 3905,8 млн грн, у 2017 році вона суттєва зросла - на 1169,6 млн грн (майже на $30 \%$ ). У результаті питома вага нарахованих сум єдиного податку у загальних надходженнях від юридичних осіб зросла із $18,35 \%$ до $21,70 \%$. Середня сума сплаченого єдиного податку юридичною особою зросла з 114,26 тис. грн до 155,56 тис. грн, або на $36,15 \%$. Питомий розмір єдиного податку збільшився з 175,52 грн/га до 248,50 грн / га, або на $41,58 \%$.

В Україні грошова оцінка земельних ділянок визначається відповідно до Закону України "Про оцінку земель" [14] і залежно від призначення та порядку прове- дення може бути нормативною і експертною. Нормативна грошова оцінка земельних ділянок використовується для визначення розміру плати за землю - земельного податку та орендної плати за земельні ділянки державної та комунальної власності. Нормативна грошова оцінка сільськогосподарських угідь в Україні станом на 01.01.2018 р. становить: рілля та перелоги - 30937,9 грн/га, багаторічні насадження - 53861,4 грн/га, природні сіножаті - 7239,3 грн/га, природні пасовища 5667,2 грн/га. Вартість земельних ділянок істотно варіює за регіонами: мінімальна вартість рілля та перелоги в Житомирській області 20581,0 грн/га, максимальна - в Черкаській (39810,8 грн/га), що в 1,93 разів більше. Максимальна вартість багаторічних насаджень 100903 грн/га в Вінницький обл., мінімальна - в 19435,5 грн/га в Тернопільській обл. (різниця у 5,19 разів). Максимальне і мінімальне значення природних сіножатей становить відповідно 14220, 1 грн/га у Во-

Таблиця 2. Аналіз кількості платників єдиного податку четвертої групи - юридичних осіб, а також обсягу їх нарахувань

\begin{tabular}{|c|c|c|c|c|}
\hline Показник & 2016 рік & 2017 рік & $\begin{array}{c}\text { Абс. } \\
\text { приріст }\end{array}$ & $\begin{array}{c}\text { Темп } \\
\text { приросту, \% }\end{array}$ \\
\hline \multicolumn{5}{|l|}{$\begin{array}{l}\text { Кількість платників - юридичних } \\
\text { осіб }\end{array}$} \\
\hline $\begin{array}{l}\text { - всього платників податку на } \\
\text { землю }\end{array}$ & 145521 & 142171 & -3350 & $-2,30$ \\
\hline - $\quad$ платники четвертої групи & 34184 & 32627 & -1557 & $-4,55$ \\
\hline $\begin{array}{l}\text { Питома вага платників єдиного } \\
\text { податку четвертої групи, \% }\end{array}$ & 23,49 & 22,95 & $-0,54$ & $\mathrm{x}$ \\
\hline \multicolumn{5}{|l|}{$\begin{array}{l}\text { Нараховано юридичними особами, } \\
\text { тис. грн }\end{array}$} \\
\hline - податку на землю & 21280128 & 23385418 & 2105290 & 9,89 \\
\hline $\begin{array}{l}\text { - } \quad \text { єдиного податку платниками } \\
\text { четвертої групи }\end{array}$ & 3905752 & 5075400 & 1169648 & 29,95 \\
\hline $\begin{array}{l}\text { Питома вага нарахованих сум } \\
\text { єдиного податку, \% }\end{array}$ & 18,35 & 21,70 & 3,35 & $\mathrm{x}$ \\
\hline $\begin{array}{l}\text { Середня сума сплаченого єдиного } \\
\text { податку, тис. грн/особа }\end{array}$ & 114,26 & 155,56 & 41,30 & 36,15 \\
\hline $\begin{array}{l}\text { Задекларована площа } \\
\text { сільськогосподарських угідь, тис. га }\end{array}$ & 22252,9 & 20423,9 & $-1829,0$ & $-8,22$ \\
\hline $\begin{array}{l}\text { Питомий розмір єдиного податку, } \\
\text { грн/га }\end{array}$ & 175,52 & 248,50 & 72,99 & 41,58 \\
\hline
\end{tabular}


линській обл. та 3165,5 грн/га у Херсонській обл. (4,49 разів різниці). По природним пасовищам ситуація аналогічна: максимум 11414,4 грн/га у Волинській області і мінімум 3165,5 грн/га у Херсонській (різниця у 3,61 разів).

У дослідженні Крамарьова О.С. переконливо доведено, що фріксований розмір земельного податку не виконує ключову функцію стимулювання раціонального використання земельних ресурсів [15, с. 97]. На думку цитованого автора, податок має залежати від сівозмін і затрат на елементи живлення, використаних рослиною для фрормування врожаю. Для підвищення ефективності механізму оподаткування земельної власності ставку податку доцільно диференціювати залежно до балів бонітету земель, що заходяться у власності платника податку, або орендуються ним. Для цього необхідно провести агрохімічну паспортизацію земель сільськогосподарського призначення. Потребує диференціації ставка податку на землю, оскільки вона зумовлює хвилю економічних наслідків, що проявляються спершу на великих агарних підприємствах, потім - на середніх і малих, пізніше - на інших секторах економіки [16, с. 180]. Зміна підходів до визначення ставки земельного податку має враховувати специфіку окремих видів сільськогосподарського виробництва, зокрема, зрошувального землеробства [17, с. 63]. Потребують вирішення питання оподаткування ПДВ операцій з придбання земельних ділянок разом із розташованими на них будівлями і спорудами [18, с. 354]. При вирішенні питання про застосування пільгової ставки земельного податку визначальною має бути реєстрація правовстановлюючих документів (державних актів на право постійного користування) із певним цільовим призначенням земельної ділянки [19, с. 45]. У розвинутих країнах Європи існує практика оподаткування землевласників за підвищеними ставками, якщо належна йому ділянка сільськогосподарського призначення не обробляється, що стимулює її використання за призначенням, або передачу в оренду, або продаж.

Більш ретельну увагу слід приділити питанням встановлення пільг по земельному податку. Відповідно до п. 28 ст. 26 Закону України "Про місцеве самоврядування в Україні" до компетенцій сільських, селищних, міських рад віднесено ухвалення рішень щодо надання пільг по місцевих податках і зборах, а також земельному податку [20]. Відповідно до статті 284 ПКУ органи місцевого самоврядування подають відповідному контролюючому органу за місцезнаходженням земельної ділянки рішення щодо ставок земельного податку та наданих пільг зі сплати земельного податку юридичним та/або фрізичним особам [11]. Стаття 27 Закону України "Про охорону земель" [21] визначає надання податкових і кредитних пільг фрізичним і юридичним особам, які здійснюють за власні кошти заходи щодо захисту земель від ерозії, підвищення родючості грунтів та інші заходи, передбачені загальнодержавними і регіональними програмами використання та охорони земель.

В умовах мораторію на відчуження земель сільськогосподарського призначення операції з передачі в оренду земельних часток (паїв) та значно розширює значення землі як об'єкта оподаткування. Селяни мають право обробляти свій пай самостійно, або передати його в оренду іншим фрізичним особам, підприємствам, агрохолдингам тощо. Враховуючи, що мінімальна плата за оренду земельного паю встановлена у відсотках від грошової оцінки і не залежить від рівня прибутковості веденого орендарем бізнесу, то власники земельних паїв отримали стабільне джерело доходу, а держава значно розширила базу оподаткування земельного капіталу. Останніми роками зростає конкуренція серед орендарів земельних паїв, що дозволяє їх власникам очікувати на зростання рівня орендної плати. Після зняття мораторію на операції купівлі-продажу сільськогосподарської землі держава буде отримувати доходи у формі державного мита від їх здійснення та від їх реєстрації в земельному кадастрі.

Податковим кодексом прямо не визначено, що робити з капітальними поліпшеннями земель, які понесені й оприбутковані орендарем у разі закінчення строку оренди. Безумовно, якщо строк оренди продовжено, то на капітальні поліпшення земельних ділянок буде нараховуватись амортизація, а якщо ні, то виникає питання, що робити із їх залишками. Отже, якщо договір операційної оренди не переукладено і на цей час капітальні поліпшення земель залишились недоамортизованими, то залишкову вартість таких поліпшень слід списати на витрати [22, с. 408]. У Законі України "Про оренду земель" зазначено, що здійснені орендарем без згоди орендодавця витрати на поліпшення орендованої земельної ділянки, які неможливо відокремити без заподіяння шкоди цій ділянці, не підлягають відшкодуванню, а також, що орендар може залишити за собою здійснені ним за власний рахунок вигоди від поліпшення орендованої земельної ділянки, якщо ці поліпшення можуть бути відокремлені без заподіяння шкоди земельній ділянці [23].

Окрім "класичного" механізму оренди, законодавство передбачає можливість суборенди - похідної передачі орендарем земельної ділянки у користування третій особі за погодженням із первинним орендодавцем на тих же умовах, на яких укладено основний договір оренди. Для вирішення спірних проблем оподаткування зазначених відносин Царук Н.Г. [24, с. 129] наведено аргументи щодо включення суборендованих земельних ділянок сільськогосподарського призначення до податкової звітності з єдиного податку IV групи суборендарів цих земель, на відміну від визначеного фіскальними органами порядку. Також запропоновано розмежування інформації про орендовані та суборендовані земельні ділянки сільськогосподарського призначення на позабалансових рахунках бухгалтерського обліку орендарів та суборендарів цих ресурсів.

У сучасних умовах виникає необхідність в розробці нових методик оцінювання вартості земельних ділянок сільськогосподарського призначення за ринковою вартістю з метою проведення транзакцій земельного ринку і формування бази оподаткування. На сьогодні і на світовому, і на європейському рівні відсутні єдині підходи і методи оцінки земельних ділянок. При визначенні податкової бази земель сільськогосподарського призначення залежно від країни може використовуватися ринкова або кадастрова вартість, коригувальні коефіцієнти до них, масова або індивідуальна оцінка. На початкових етапах формування ринку землі, які супровод- 
жуються браком достатньої інформації про ціни договорів купівлі-продажу, у зарубіжній практиці використовують масову оцінку сільськогосподарських угідь це метод отримання вартісних оцінок однорідної групи земельних ділянок з використанням ринкової інформації про угоди окремих із них. На подальших етапах по мірі накопичення статистичних даних здійснюється перехід до індивідуальної оцінки ринкової вартості земельних ділянок.

\section{ВИСНОВКИ 3 ПРОВЕАЕНОГО АОСАІАЖЕННЯ І ПЕРСПЕКТИВИ ПОАААЬШИХ РОЗВІАОК У ЦЬОМУ НАПРЯМІ}

Для зростання ролі оподаткування земельної власності у розвитку аграрного сектора економіки доцільно: реформувати підходи до надання пільг - встановлювати їх відповідно до об'єкта, а не платника податку, а також ув'язувати з реалізацією загальнодержавних і регіональних програм розвитку земельного ринку і охорони земель; провести еколого-агрохімічну паспортизацію і інвентаризацію земель на предмет відповідності об'єкту оподаткування; здійснювати поступовий перехід до використання ринкової вартості землі як бази оподаткування; диференціювати земельну нерухомість за рівнями якості сільськогосподарських угідь, у т.ч. із виділенням поліпшених земель і таких, що потребують поліпшення; ввести фрінансові і адміністративні санкції за неналежне використання сільськогосподарських земель і недотримання екологічних норм; стимулювати засобами податкової політики збільшення терміну оренди рілля і багаторічних насаджень для забезпечення відповідального ставлення орендарів; унеможливити оподаткування земельного капіталу великих сільськогосподарських суб'єктів оподаткування за спеціальними режимами, призначеними для малих організаційних форм агробізнесу. Обов'язковою умовою відміни мораторію на здійснення операцій відчуження сільськогосподарської землі $є$ створення відповідної інфрраструктури земельного ринку, автоматизованої системи ведення державного земельного кадастру, спрямованого на вирішення питань обліку земель, надходжень від плати за землю, контролю їх повноти і своєчасності.

Метою подальших досліджень $є$ розробка іпотечних механізмів у системі стимулювання розвитку аграрного ринку.

\section{Література:}

1. Павленко Е.Б. До питання про правову природу податку на землю як різновиду прямих податків. Наукові записки Львівського університету бізнесу та права. - 2012. - Вип. 9. - С. 84-86.

2. Нудьга М. В. Аналіз надходжень податку на землю до бюджету Харківської області. Управління розвитком. - 2014. - № 5. - С. 99-100.

3. Легенченко М.О. Особливості сплати земельного податку у правовідносинах оренди комунального майна. Науковий часопис НПУ імені М.П. Драгоманова. Серія 18: Економіка і право. - 2012. - Вип. 17. - С. 119-124.

4. Тесля Л.В. Розробка та реалізація політики місцевих податків і зборів в селищах з землями рекреаційно- го призначення. Актуальні проблеми держави і права. - 2005. - Вип. 26. - С. 140-143.

5. Левицька С.О., Стець Н.В. Методичні та прикладні підходи ефективності землекористування в умовах податкового реформування. Наукові записки Національного університету "Острозька академія". Серія: Економіка. - 2016. - Вип. 1. - С. 104-109.

6. Кухта К.О., Джура В.В. Історичний генезис адміністрування земельного податку в Україні: сучасні аспекти та еволюція розвитку земельного оподаткування. Інвестиції: практика та досвід. - 2019. - № 2. С. $42-47$.

7. Статистичний щорічник "Моніторинг земельних відносин в Україні: 2016-2017". - К.: Державна служба геодезії, картографії і кадастру, 2018. URL: http:// land.gov.ua/wp-content/uploads/2018/10/monitoring.pdf

8. Про фріксований сільськогосподарський податок: Закон України від 17.12.1998 № 320-XIV. URL: https:/ /zakon.rada.gov.ua/laws/show/320-14 (Закон втратив чинність на підставі Кодексу № 2755-VI від 02. 12.2010, BBP, 2011, № 13-14, № 15-16, N 17, ст.112)

9. Дема Д.І., Сус Ю.Ю., Трокоз В.М. Податкові наслідки реформування земельних відносин. Вісник Житомирського національного агроекологічного університету. - 2011. - № 2 (2). - С. 369-375.

10. Про внесення змін до Податкового кодексу України та деяких законодавчих актів України щодо податкової рефрорми: Закон України від 28.12.2014 № 71 VIII. URL: https://zakon.rada.gov.ua/laws/show/7119\#n 1664

11. Податковий кодекс України: Закон України від 02.12.2010 № 2755-VI. URL: https://zakon.rada.gov.ua/ laws $/$ show $/ 2755-17$ ? find $=1$ \& text $=\%$ F $1 \%$ F $\%$ E0 \%F2\%F2\%FF+14\#w11

12. Гривнак К. Про звільнення платників єдиного податку четвертої групи від сплати земельного податку. Землевпорядний вісник. - 2015. - № 3. - С. 5051.

13. Бюджетний кодекс України: Закон України від 08.07.2010 № 2456-VI. URL: https://zakon.rada.gov.ua/ laws/show/2456-17

14. Про оцінку земель: Закон України від 11.12.2003 № 1378-IV. URL: https://zakon.rada.gov.ua/laws / show/1378-15

15. Крамарьов О.С. Обгрунтування структури земельного податку в контексті ефективного використання земельних ресурсів. Облік і фрінанси. - 2018. № 1. - С. 93-98.

16. Григорків В.С., Іщенко С.В. Моделювання фрінансових потоків власників землі сільськогосподарського призначення з урахуванням впливу податків. Науковий вісник Чернівецького університету. Сер. Економіка. 2015. - Вип. 730-731. - С. 175-182.

17. Цап В.Д. Проблеми витрат виробництва зрошувального землеробства в умовах сучасних змін у податковому законодавстві. Економіка АПК. - 2018. № 6. - С. $57-66$.

18. Цебень Р.Л. Особливості руху земельних ділянок: аспекти фрінансового та податкового обліку. Вісник Хмельницького інституту регіонального управління та права. - 2004. - № 1-2. - С. 351-357. 
19. Бахуринська М.М. Новели правового регулювання земельного податку із земель залізничного траспорту за Податковим кодексом України. Бюлетень Міністерства юстиції України. - 2011. - № 7. - С. 41-46.

20. Про місцеве самоврядування в Україні: Закон України від 21.05.1997 № 280/97-BP. URL: https:// zakon.rada.gov.ua/laws/show /280/97-\%D0\%B2\%D1\% 80

21. Про охорону земель: Закон України від 19.06.2003 № 962-IV. URL: https://zakon.rada.gov.ua/ laws/show/962-15

22. Лень В.С. Стан та облікові й податкові аспекти поліпшення орендованих земельних ділянок. Вісник Чернігівського державного технологічного університету. Серія: Економічні науки. - 2013. - № 2. - С. 402411.

23. Про оренду землі: Закон України від 06.10.1998 № 161-XIV. URL: https://zakon.rada.gov.ua/laws/ show / 161-14

24. Царук Н.Г. Відображення суборендованих земель у податковій звітності та бухгалтерському обліку платників єдиного податку IV групи. Економіка. Фінанси. Менеджмент: актуальні питання науки і практики. 2017. - № 8. - C. 118-131.

\section{References:}

1. Pavlenko, E. B. (2012), "To the question of the legal nature of the land tax as a kind of direct taxes", Naukovi zapiski L'vivs'kogo universitetu biznesu ta prava, vol. 9, pp. 84-86.

2. Nud'ga, M. V. (2014), "Analysis of the land tax revenues to the budget of the Kharkiv region", Upravlinnja rozvitkom, vol. 5, pp. 99-100.

3. Legenchenko, M. O. (2012), "Features of the payment of land tax in the legal relations of lease of communal property", Naukovij chasopis NPU imeni M. P. Dragomanova. Serija 18: Ekonomika i pravo, vol. 17, pp. $119-$ 124.

4. Teslja, L. V. (2005), "Development and implementation of the policy of local taxes and fees in settlements with recreational lands", Aktual'ni problemi derzhavi i prava, vol. 26, pp. 140-143.

5. Levic'ka, S. O. and Stec', N. V. (2016), "Methodological and applied approaches to land use efficiency in tax reform", Naukovi zapiski Nacional'nogo universitetu "Ostroz'ka akademija". Serija: Ekonomika, vol. 1, pp. 104-109.

6. Kuhta, K. O. and Dzhura, V. V. (2019), "Historical genesis of land tax administration in Ukraine: current issues and evolution of land tax development", Investiciï: praktika ta dosvid, vol. 2, pp. 42-47.

7. The State Service of Ukraine for Geodesy, Cartography \& Cadastre (2018), "Statistical and Yearbook "Monitoring Land Relations in Ukraine: 2016-2017", available at: http://land.gov.ua/wp-content/uploads / 2018/10/monitoring.pdf (Accessed 25 March 2019).

8. Verkhovna Rada of Ukraine (1998), The Law of Ukraine "On the fixed agricultural tax", available at: available at: https://zakon.rada.gov.ua/laws/show/ 320-14 (Accessed 25 March 2019).

9. Dema, D. I. Sus, Ju. Ju. and Trokoz, V. M. (2011), "Tax implications of the reformation of land relations",
Visnik Zhitomirs'kogo nacional'nogo agroekologichnogo universitetu, vol. 2(2), pp. 369-375.

10. Verkhovna Rada of Ukraine (2014), The Law of Ukraine "On Amendments to the Tax Code of Ukraine and Certain Legislative Acts of Ukraine on Tax Reform", available at: available at: https://zakon.rada.gov.ua/ laws/show /71-19\#n1664 (Accessed 25 March 2019).

11. Verkhovna Rada of Ukraine (2010), "The Tax Code of Ukraine", available at: available at: https://zakon.rada.gov.ua/laws $/$ show $/ 2755-17$ ?find $=1$ \&text $=\% \mathrm{~F} 1 \%$ F2\%E0\%F2\%F2\%FF+14\#w11 (Accessed 25 March 2019).

12. Grivnak, K. (2015), "On the dismissal of the single tax payers of the fourth group from the payment of land tax", Zemlevporjadnij visnik, vol. 3, pp. 50-51.

13. Verkhovna Rada of Ukraine (2010), "The Budget Code of Ukraine", available at: available at: https:// zakon.rada.gov.ua/laws/show/2456-17 (Accessed 25 March 2019).

14. Verkhovna Rada of Ukraine (2003), The Law of Ukraine "On land valuation", available at: available at: https://zakon.rada.gov.ua/laws/show/1378-15 (Accessed 25 March 2019).

15. Kramar'ov, O. S. (2018), "Justification of the structure of land tax in the context of efficient use of land resources", Oblik i finansi, vol. 1, pp. 93-98.

16. Grigorkiv V. S. and Ishhenko S. V. (2015), "Modeling of financial flows of agricultural land owners taking into account the influence of taxes", Naukovij visnik Chernivec'kogo universitetu. Ser. Ekonomika, vol. 730731, pp. $175-182$.

17. Cap, V. D. (2018), "Problems of the cost of irrigation farming in the context of modern changes in tax legislation". Ekonomika APK, vol. 6, pp. 57-66.

18. Ceben', R. L. (2004), "Features of land movement: aspects of financial and tax accounting", Visnik Hmel'nic'kogo institutu regional'nogo upravlinnja ta prava, vol. $1-2$, pp. $351-357$.

19. Bahurins'ka, M. M. (2011), "Notices of legal regulation of land tax on land of railways under the Tax Code of Ukraine", Bjuleten' Ministerstva justiciï Ukraïni, vol. 7 , pp. $41-46$.

20. Verkhovna Rada of Ukraine (1997), The Law of Ukraine "On Local Self-Government in Ukraine", available at: available at: https://zakon.rada.gov.ua/laws/show / 280/97-\%D0\%B2\%D1\%80 (Accessed 25 March 2019).

21. Verkhovna Rada of Ukraine (2003), The Law of Ukraine "On the protection of land", available at: available at: https://zakon.rada.gov.ua/laws/show /962-15 (Accessed 25 March 2019).

22. Len', V. S. (2013), "Status and accounting and tax aspects of improvement of leased land plots", Visnik Chernigivs'kogo derzhavnogo tehnologichnogo universitetu. Serija: Ekonomichni nauki, vol. 2, pp. 402-411.

23. Verkhovna Rada of Ukraine (1998), The Law of Ukraine "On lease of land", available at: available at: https://zakon.rada.gov.ua/laws/show/161-14 (Accessed 25 March 2019).

24. Caruk, N. G. (2017), "Representation of sub-leased land in tax reporting and accounting of single tax payers of group IV", Ekonomika. Finansi. Menedzhment: aktual'ni pitannja nauki i praktiki, vol. 8, pp. 118-131.

Статтл надійшла до редакції 01.04.2019p. 